\title{
Stomatal density, leaf area and plant size variation of Rhizophora mangle (Malpighiales: Rhizophoraceae) along a salinity gradient in the Mexican Caribbean
}

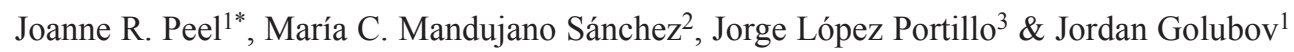

1. Universidad Autónoma Metropolitana, Departamento El Hombre y Su Ambiente, Calzada Del Hueso 1100, Colonia Villa Quietud, Coyoacán, 04960 Distrito Federal, México; jrpeel@gmx.de, gfjordan@correo.xoc.uam.mx

2. Instituto de Ecología, Universidad Nacional Autónoma de México, Apartado postal 70-275, Coyoacán, 04510 Distrito Federal, México; mcmandujano@gmail.com

3. Instituto de Ecología, A.C., Red de Ecología Funcional, Carretera antigua a Coatepec 351, 91070 Xalapa, Veracruz, México; jorge.lopez.portillo@inecol.mx

Received 15-V-2016. Corrected 12-XII-2016. Accepted 17-I-2017.

\begin{abstract}
In community ecology, the knowledge of abiotic factors, that determine intraspecific variability in ecophysiological and functional traits, is important for addressing major questions, such as plant community assembly and ecosystem functioning. Mangroves have several mechanisms of resistance to salinity and most species exhibit some xeromorphic features in order to conserve water. Leaf area and stomatal density play an important role in maintaining water balance, and gas exchange is regulated by their aperture and density, two traits that vary intraspecifically in response to environmental conditions, such as water stress and salinity. In this study, we evaluated the effects of salinity on stomatal density, leaf area and plant size in $R$. mangle and we tested for associations among the three variables, across three sites along a natural salinity gradient in the XelHá Park, Quintana Roo, Mexico. We hypothesized that high salinity sites would produce smaller plants, with smaller leaves, and fewer stomata. Three sampling sites with different environmental conditions were chosen and salinities were monitored monthly. A total of 542 plants were tagged and tree heights and diameters were measured for each individual within each of the three sampling sites. Three leaves from 20 trees from each site were measured to determine leaf area. Stomatal densities were determined in each leaf using nail polish casts, examining ten $1 \mathrm{~mm}$ squares per leaf under an optical microscope. A principal component analysis was used to assess association between tree height, leaf area, and stomatal density for each plot. The salinity gradient was reflected in plant size, producing smaller plants at the higher salinity site. The largest leaves were found at the low salinity site $\left(51.2 \pm 24.99 \mathrm{~cm}^{2}\right)$. Leaf length was not correlated to plant size (LL vs. tree height: $\mathrm{r}=0.02$, $\mathrm{P}=0.8205$; LL vs. trunk diameter: $\mathrm{r}=0.03, \mathrm{P}=0.7336$ ), so we concluded that leaf length is an environmentally plastic trait of red mangroves that may vary as a function of environmental conditions, such as hydric stress caused by elevated salinity. The larger leaves from the low salinity site had lower densities of stomata (65.0 stomata. $\mathrm{mm}^{2} \mathrm{SD}=12.3$ ), and increasing salinities did not decrease stomatal density (intermediate salinity site: 73.4 stomata. $\mathrm{mm}^{2} \mathrm{SD}=13.5$; high salinity site: 74.8 stomata. $\mathrm{mm}^{2} \mathrm{SD}=17.3$ ). Our results confirm that stomatal density is inversely related to leaf area ( $\mathrm{r}=-0.29, \mathrm{P}<0.001)$, especially leaf width $(\mathrm{r}=-0.31, \mathrm{P}<0.001)$, and that salinity may increase stomatal density by causing reduction of leaf size. Rev. Biol. Trop. 65 (2): 701-712. Epub 2017 June 01.
\end{abstract}

Key words: leaf plasticity, leaf area, mangroves, tree height, stomatal densities, water stress.

Mangroves are an ecological group of tropical plants which inhabit coastal environments (Tomlinson, 1986). They are normally found in flooded areas or close to water, where they can experience variable mixtures of fresh and seawater, and often experience salt concentrations higher than seawater in the substrate, which forces mangroves to absorb water against an osmotic pressure gradient (Connor, 1969; Downton, 1982; Ball \& Pidsley, 1995; 
Aziz \& Khan, 2001; Saenger, 2002). All mangroves show some traits of salt resistance that require metabolic energy, which may include salt exclusion, salt extrusion, salt storage, succulence, compartmentalization and osmo-compensation (Saenger, 2002). Many mangroves have also developed some xeromorphic features in order to conserve water, including a thick-walled multi-layered epidermis, thick waxy lamellar cuticle, and hairs or scales on the abaxial surface which cover salt glands and stomata (Ball, 1988; Das \& Ghose, 1993; Saenger, 2002).

Four dominant species of mangroves can be found in Mexican coasts: Rhizophora mangle L., Laguncularia racemosa (L.) C.F. Gaertn., Avicennia germinans L. and Conocarpus erectus L. (López-Portillo \& Ezcurra, 2002; CONABIO, 2009). The red mangrove (R. mangle) is an important species in tropical North and South America and West Africa, and is one of the most dominant species within its range (Mehlig, 2006), nevertheless, it is threatened by habitat conversion and pollution, which has resulted in declines throughout the wider Caribbean region (Ellison, Farnsworth, \& Moore 2015). The extended distribution and dominance of this species may be partially attributed to its extreme tolerance to a range of environmental conditions, resisting waterlogged soils and high salinities up to $90 \mathrm{ppt}$ (Hill, 2001). Salt uptake of $R$. mangle is mainly regulated by the root system, which excludes most salts during water uptake, while the other mangrove species (e. g. Avicennia germinans and Laguncularia racemosa) take up seawater through their roots but excrete excess salt through pores or salt glands on the leaf surface (Duke, 1983). Growth of $R$. mangle appears to peak at moderate salinities (10 PSU). At higher salinities (32 PSU) leaf area and photosynthetic potential decrease (Krauss \& Allen 2003), indicating that the leaves of $R$. mangle play a major role in osmoregulation. Larger leaves have thicker boundary layers of still air lowering convective heat loss, enabling a high variation between ambient and leaf temperature. This may be a disadvantage as respiration increases more than photosynthesis with temperature and the effect is more important for leaves under stronger radiation and where water is in short supply (Westoby, Falster, Moles, Vesk, \& Wright, 2002). Leaves of the red mangrove are oval shaped or elliptic, $6-10 \mathrm{~cm}$ long, hairless, and tend to be relatively uniform (Tomlinson, 1986). However, leaf area may be variable (Araujo, Jaramillo, \& Snedaker, 1997) and reduced under suboptimal conditions and so can be an indicator of chronic environmental stress (Canoy, 1975; Snedaker \& Brown, 1981). Known stressors include high salinity, latitudinal location, exposure to pollutants (Lugo \& Snedaker, 1974; Lugo, Cintrón, \& Goenaga, 1981) and height induced water stress (Zhang, Zheng, \& Tyree, 2012), so therefore, leaf area can be considered an indicator of chronic environmental stress (Araujo et al., 1997).

Gas exchange is mediated on one hand by regulating stomata aperture, and on the other, by controlling the number of stomata (Hetherington \& Woodward 2003). Several environmental conditions can affect the morphogenesis of stomata, such as water availability (Salisbury, 1928; Xu \& Zhou. 2008), temperature (Ciha \& Brun, 1975; Huner, Palta, Li, \& Carter, 1981), light exposure (Gay \& Hurd, 1975), and environmental $\mathrm{CO}_{2}$ concentrations (e.g. Salisbury, 1928; Bristow \& Looi, 1968; Woodward \& Bazzaz, 1988; Beerling \& Kelly, 1997). Water stress has been associated with a reduction of stomatal density in leaves (Salisbury, 1928; Pääkkönen, Vahala, Pohjolal, Holopainen, \& Kärenlampi, 1998; Sam, Jeréz, Dell'Amico, \& Ruiz-Sanchez 2000; RomeroAranda, Soria, \& Cuartero, 2001; Xu \& Zhou, 2008; Barbien et al., 2012), however, it may also lead to higher stomatal densities if there is an overall reduction of leaf area (Ciha \& Brun, 1975; Romero-Aranda et al., 2001; Pearce, Millard, Bray, \& Rood, 2005; Xu \& Zhou, 2008). Mangrove stomata are similar in terms of frequency and dimension to those of other plants from other environments, but many species have stomatal crypts (e.g. Avicennia, Aegiceras, Bruguiera, Ceriops, Heritiera, Lumnitzera, Nypa), resulting in the formation 
of substomatal chambers, in order to deal with the water stress of a saline environment. (Das \& Ghose, 1993; Saenger, 2002).

The aim of this paper was to evaluate the effects of salinity on stomatal density, leaf area, plant height and diameter of Rhizophora mangle, and to determine if there was an association between these variables in three different sites that provide a natural salinity gradient. We hypothesized that lower salinity would lead to higher stomatal density, increased leaf area and greater tree height, because plants would be less water-stressed. In contrast, high salinity environments would produce smaller plants, with smaller leaves and fewer stomata. Support for this would contribute to our understanding of the environmental factors that promote intraspecific variability in ecophysiological and functional traits that are critical for plant function regarding water-gas exchange and biomass accumulation. Intraspecific trait variation may account for $25 \%$ of the total trait variation of a community (Siefert et al., 2015). Knowledge of intraspecific trait variation in leaf area, stomatal density and tree height might help us improve our forecasts of carbon ecosystem budgets and our evaluations of the global and regional water cycle.

\section{MATERIALS AND METHODS}

Study site: The study was carried out in Xel-Há cove $\left(20^{\circ} 19^{\prime} 15^{\prime}\right.$ ' $\mathrm{N}-87^{\circ} 21^{\prime} 41^{\prime}$ 'W \& $\left.20^{\circ} 18^{\prime} 50^{\prime \prime} \mathrm{N}-87^{\circ} 21^{\prime} 15^{\prime \prime} \mathrm{W}\right)$ in the state of Quintana Roo, in the East coast of Yucatan Peninsula, $16 \mathrm{~km}$ Northeast from the city of Tulum. The area has an intermediate tropical and subhumid climate, with rains somewhat distributed throughout the year, with a tendency of higher rainfall during summer, and rain during winter (Ax' $\left(\mathrm{w}_{1}\right)$ iw, Orellana-Lanza, Espadas, Conde, \& Gay, 2009). The cove is connected to the Caribbean Sea by a channel that is about $90 \mathrm{~m}$ wide and $170 \mathrm{~m}$ long, has a central canal and two tributaries that drain towards the sea: North Arm and South Arm. The area is characterized by a pronounced and persistent salinity gradient over a short distance, the result of a mix of underground freshwater and seawater (Organismo de Cuenca Península de Yucatán, 2008).

In January 2014 the entire area was explored, salinities were determined at several points using an YSI 650 MDS multiparameter probe (YSI Inc. Yellow Springs, OH, USA) and accessibility of $R$. mangle mangrove populations were assessed. Three sampling sites with different environmental conditions were chosen for their accessibility and salinity: River, Lagoon and Beach. The sites are separated from each other by at least $300 \mathrm{~m}$. Plot limits were based on the natural limits and features of each site. Salinities were monitored monthly from May 2014 to February 2015 at 5 different points within each of the sampling plots.

The River site was located in the Southern arm section $\left(20^{\circ} 18^{\prime} 52^{\prime \prime} \mathrm{N}-87^{\circ} 21^{\prime} 40^{\prime \prime} \mathrm{W}\right)$, where a $10 \mathrm{~m}$ x $30 \mathrm{~m}$ sampling plot was established parallel to the river. Salinity was measured as 15.5 PSU in the water surrounding the plants. The substrate was black to red mud mixed with high amounts of litterfall produced by the mangroves in decomposition. The Lagoon site was located in the Northern part of the cove $\left(20^{\circ} 19^{\prime} 11^{\prime \prime} \mathrm{N}-87^{\circ} 21^{\prime} 30.39^{\prime \prime} \mathrm{W}\right)$, where a 3 $\mathrm{m} \times 6 \mathrm{~m}$ sampling plot was established. The salinity initially registered was 26.5 PSU in the water surrounding the mangrove plants. The soil was black mud with high amounts of litterfall and some scattered boulders. The Beach site $\left(20^{\circ} 18^{\prime} 52^{\prime \prime} \mathrm{N}-87^{\circ} 21^{\prime} 23^{\prime \prime} \mathrm{W}\right)$ is a small bay within the channel that connects the cove to the ocean in which salinities of 31.5 PSU were recorded in the $10 \times 3 \mathrm{~m}$ plot. At this site, mangroves develop directly on the sandy beach.

\section{Stomatal densities and plant morphom-} etry: We tagged all plants within each plot, and for each plant, we measured basal stem circumference with a standard measuring tape, taking measurements just above the first pair of aerial roots. Diameters were then calculated from stem circumference. The total height of the plant was also measured along the main axis of the trees, using a standard measuring tape and a telescopic pole. 
Three healthy mature leaves (i.e., fully expanded, non-senescent) of 20 different individuals in each plot were collected from the distal ends of branches exposed to full sunlight. Leaf length (LL) and width (LW) were measured for each leaf, and nail polish casts were prepared for stomatal observations (Brewer, 1992). The complete abaxial surface of each leaf was covered with transparent nail polish and left to dry for about $5 \mathrm{~min}$. Once dry, the cast was removed using transparent adhesive tape, resulting in an impression of the leaf surface, which was then observed under a Leica Zoom 2000 stereoscope $45 \times$ using a millimeter grid. All stomata within $1 \mathrm{~mm}$ squares were counted, taking measurements from 10 squares on the leaf surface, avoiding the leaf edge and areas close to the central rib.

Statistical analysis: Average salinities and standard error were obtained for each month at each site. ANOVA was used to determine whether salinity differed significantly between sites over the duration of the study. The analysis was performed with InfoStat $\mathrm{S}$ (Universidad Nacional de Córdoba, Argentina). Stomatal counts were averaged per leaf for further analysis. Averages and standard deviation were calculated for stomatal density, leaf length and leaf width for each site for comparison. Leaf area $(\mathrm{LA}=\Pi *(\mathrm{LL} / 2) *(\mathrm{LW} / 2))$ and leaf slenderness $(\mathrm{LS}=\mathrm{LL} / \mathrm{LW})$ were calculated per individual / site / date. All variables were tested for normality using Shapiro-Wilks normality tests. An analysis of variance (ANOVA) was used to detect significant differences between leaf width, leaf length, leaf area, slenderness and stomatal density between sampling sites, followed by multiple comparison Tukey HSD tests. Tree heights and stem diameters did not show normal distribution within sites, and differences between sites were therefore tested using nonparametric Kruskal-Wallis ANOVA. Association between variables was tested through Pearson correlations.

A principal component analysis (JMP ver. 10.0.0, SAS Institute Inc., Cary, NC, USA) was used to determine the relationship between all parameters among sites. All leaf traits (LL, LW, LA, LS and stomatal densities) were averaged per plant before carrying out the analysis. All variables were correlated with the resulting PCA axis to determine their contribution to the resulting components.

\section{RESULTS}

Salinities differed across sites $\left(\mathrm{F}_{2,134}=\right.$ 214.77; $\mathrm{P}<0.0001$ ) but were stable throughout the year within sites (Fig. 1). River had the lowest salinities, with an average salinity of $8.4(\mathrm{SD}=1.20)$, followed by Lagoon with an average salinity of $13.7(\mathrm{SD}=3.71)$, and Beach had the highest salinities (Average $=18.8 \mathrm{SD}=$ 1.42). A total of 542 plants were tagged at the three sampling plots. The highest density of plants was recorded at the Beach site (11.5 ind/ $\mathrm{m}^{2}$ ) followed by the Lagoon site (density $=9.05$ ind $/ \mathrm{m}^{2}$ ) while the River site only contained 33 plants $\left(0.11 \mathrm{ind} / \mathrm{m}^{2}\right)$. The salinity gradient was reflected in plant size and differed significantly between sites (Table 1, Fig. 2). The Beach site (highest salinity) had plants shorter than $3.5 \mathrm{~m}$, while the Lagoon site had individuals mostly shorter than $3 \mathrm{~m}$ with some exceptions (individuals could reach $7 \mathrm{~m}$ ). Finally, at the River site most individuals $(90 \%)$ were consistently taller than $5 \mathrm{~m}$.

Significant differences were found for all the measured variables between sites (Table 1). Leaf width ranged between $1.9 \mathrm{~cm}$ (Beach site) and $6.8 \mathrm{~cm}$ (River site) (Table 1). Leaf length varied between $6.1 \mathrm{~cm}$ and $15.9 \mathrm{~cm}$ (Table 1), and significant differences between sites were found regarding leaf slenderness $\left(\mathrm{F}_{2,179}=46.3\right.$; $\mathrm{P}<0.0001)$ and leaf area $\left(\mathrm{F}_{2,179}=28.5 ; \mathrm{P}<\right.$ 0.0001; Table 1 and Fig. 3), with the thinnest leaves collected at the River site (Fig. 3) and the largest leaves (highest leaf area) at the River site, while the smallest leaves corresponded to the Lagoon site (Fig. 3).

Within each of the sites, stomatal densities (stomata. $\mathrm{mm}^{-2}$ ) showed a wide range 54.5102.5 stomata. $\mathrm{mm}^{-2}$ on Beach leaves, 52.9-97.0 stomata. $\mathrm{mm}^{-2}$ on Lagoon leaves, and 45.587.4 stomata. $\mathrm{mm}^{-2}$ on River leaves (Table 1, 


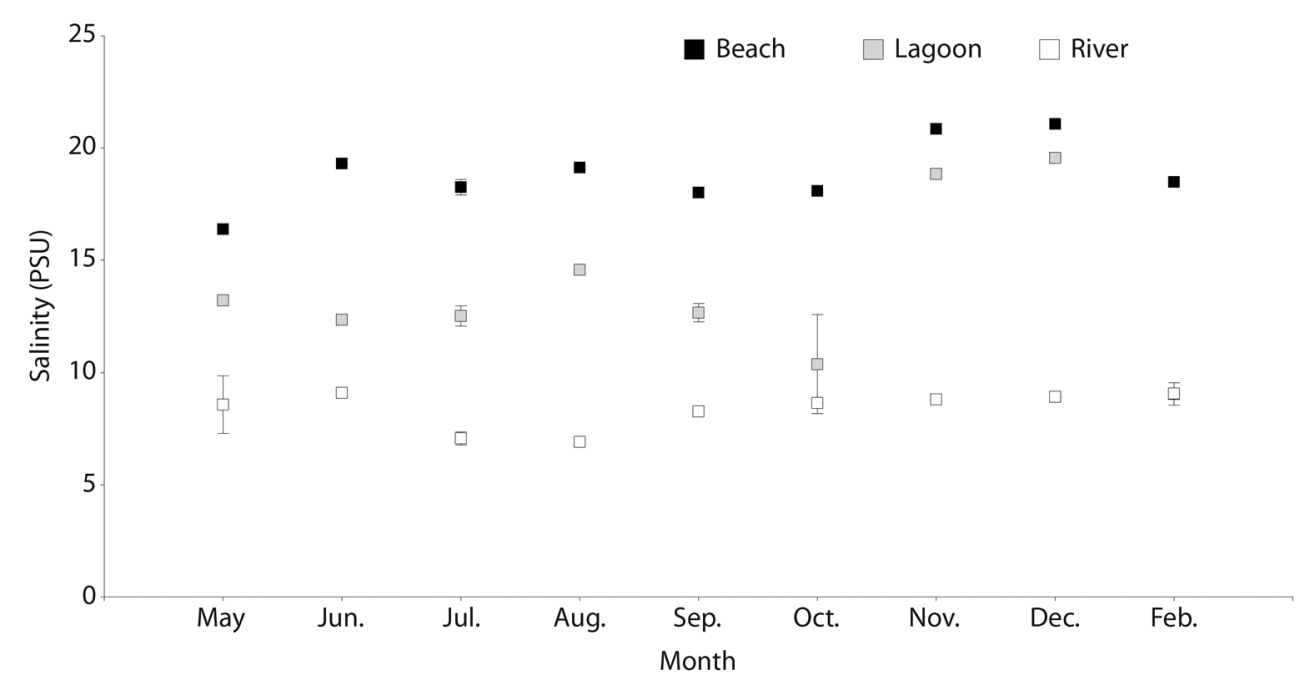

Fig. 1. Average salinities (PSU) and standard error, registered at the three sampling sites River; Lagoon; and Beach at the Xel-Há cove (XH), Quintana Roo, Mexico.

TABLE 1

Range and average ( \pm standard deviation) salinities, leaf width, leaf length, leaf area, leaf slenderness, tree height, stem diameter and stomatal density (stomata/ $\mathrm{mm}^{2}$ ), of Rhizophora mangle collected at three different sites (River, Lagoon and Beach) of the Xel-Há cove, Quintana Roo, Mexico, and statistical differences between the measured variables between sites

$\begin{array}{llcccc} & & & \text { Sites } & \text { Statistical differences } \\ \text { between sites }\end{array}$

Fig. 3). Differences in stomatal density could be explained by differences in the leaves from the River $(\mathrm{P}<0.05)$, which had significantly lower stomatal densities (stomata. $\mathrm{mm}^{-2}$ ), while there were no significant differences between the Lagoon and Beach sites (P > 0.05; Fig. 3).
Stomatal density showed significant (P $<0.001)$ negative correlations with LW, LL, LA, stem diameter and tree height (Table 2). Leaf width was positively correlated with LL, LA, diameter and tree height (Table 2). However, LL was not correlated with neither 


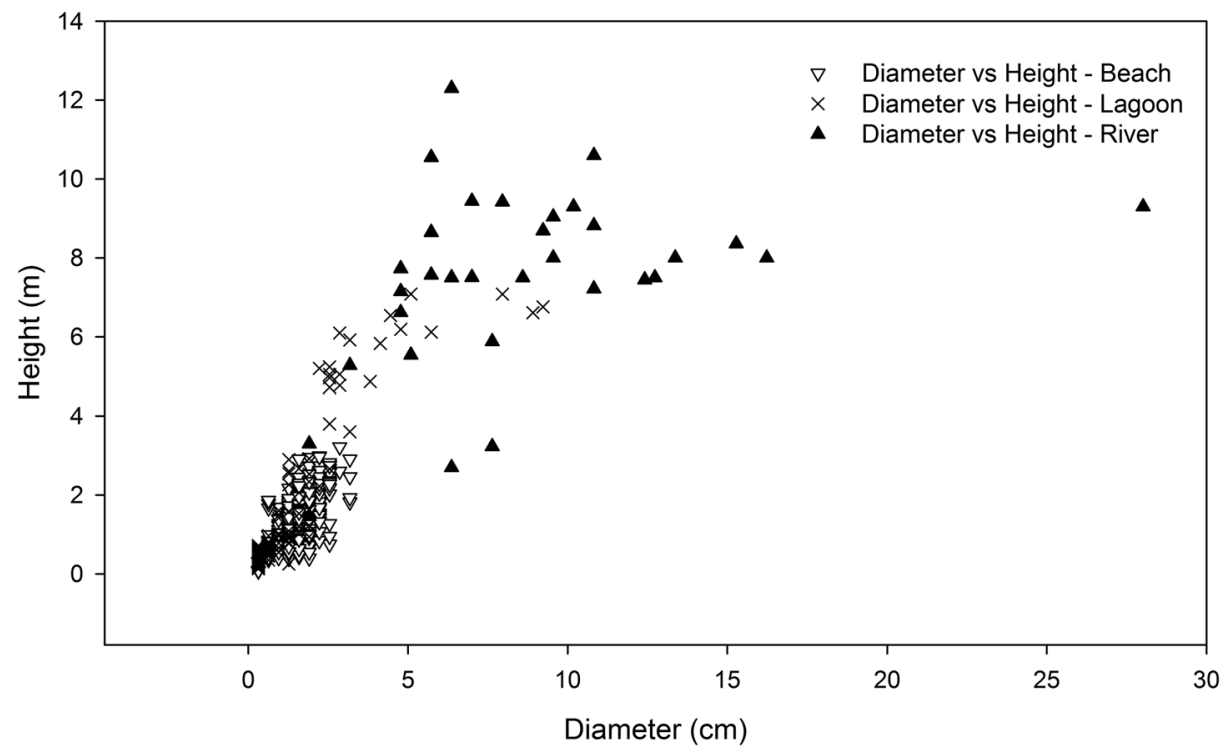

Fig. 2. Trunk diameter (cm) vs. tree height (m) of Rhizophora mangle plants at the three sampling plots River (triangle), Lagoon (crosses) and Beach (inversed triangle), in the Xel-Há Park, Quintana Roo, Mexico.

height nor diameter (Table 2). LA and LS were collinear, both being derived from LL and LW. We feel that LA was the more informative variable and so included LA and not LS in the PCA (Table 2). Tree diameter and height were also found to be strongly associated, so height was chosen to represent plant size, since it generally showed stronger association with the leaf trait variables (Table 2).

The principal component analysis (Fig. 4) differentiated among sites, especially segregating the trees from the River and Beach sites. The first principal component accounted for $53.7 \%$ of the total variation. It was inversely correlated with stomatal density $(-0.29)$, and directly correlated with tree height $(0.30)$ and diameter (0.29), as well as, leaf area (0.51), leaf width (0.52), and length (0.44). The second principal component accounted for $27.40 \%$ of the total variability of the data and showed strong inverse correlation with tree height $(-0.55)$ and diameter (-0.56). The strongest positive association of the second component was with leaf length (0.44) (Fig. 4). The principal component scores were considered as an index summarizing all measured variables and were used to correlate each parameter in order to determine their contribution to each of the PCA axes (Table 3). All variables were significantly correlated with component 1 . The highest correlations were with leaf length, trunk diameter, and inversely with leaf area. Only three variables were significantly correlated with component 2: leaf length, trunk diameter and height (Table 3 ).

\section{DISCUSSION}

Plant size varied among sampled sites and reflected the salinity gradient, with the largest plants at the lowest salinity site and smaller plants at the higher salinity sites. This result is consistent with previous findings that plant growth in mangroves is affected by salinity. For example, in $R$. mucronata sapling growth declines above $50 \%$ seawater and in Bruguiera parviflora growth declines, with further increases in salinity (Aziz \& Khan, 2001). In B. parviflora, plant growth decreases with 200 and $400 \mathrm{mM} \mathrm{NaCl}$ treatments 

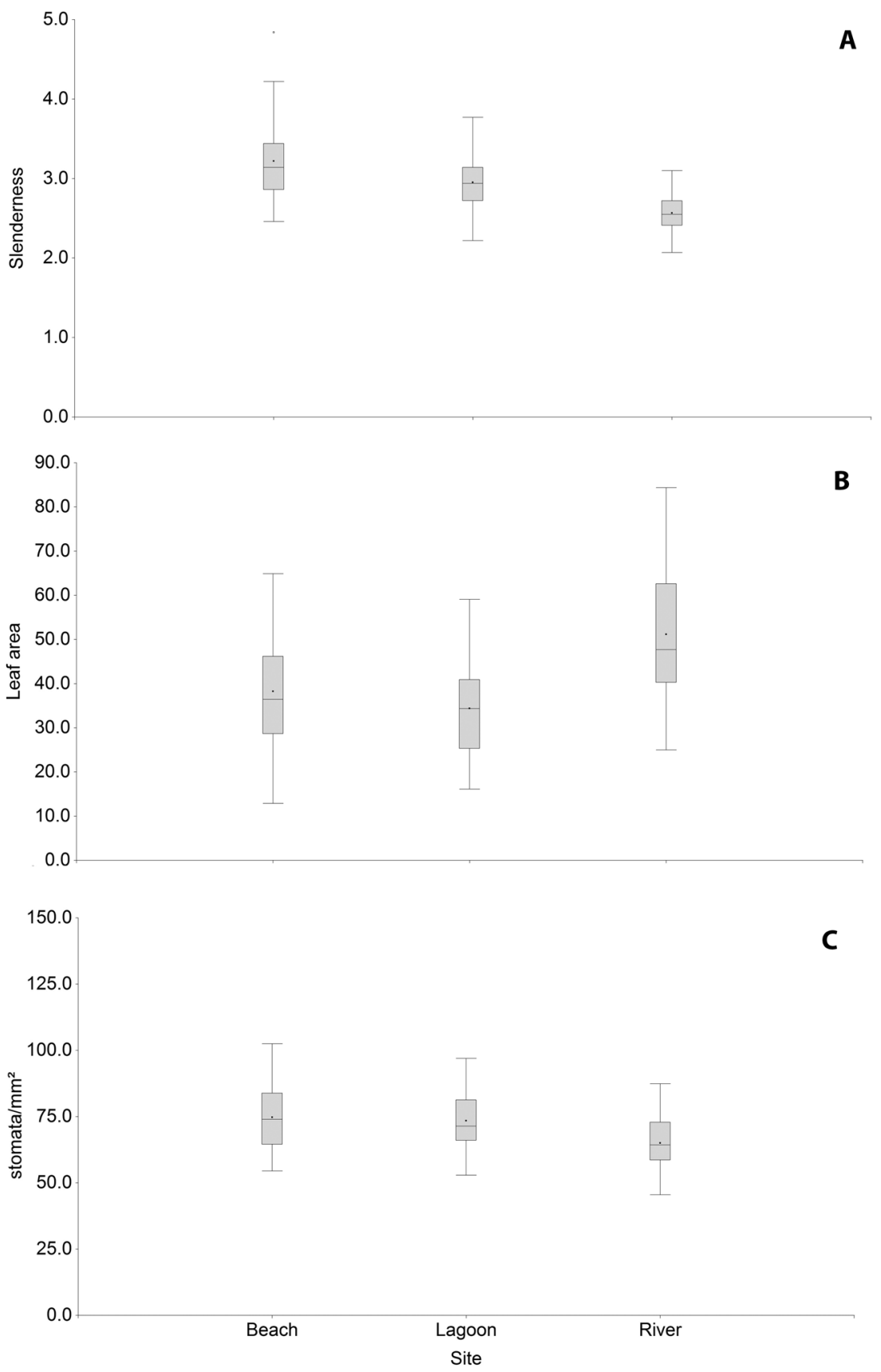

Fig. 3. Average, median and standard deviation of (A) leaf slenderness ( $\mathrm{S}=$ Length/width), (B) leaf area, and (C) stomatal density $/ \mathrm{mm}^{2}$ of Rhizophora mangle, sampled at three different sites (River, Lagoon, Beach) of the Xel-Há Park, Quintana Roo, Mexico, and Tukey contrasts $(A, B C$, smallest to largest value, means with a common letter are not significantly different $(\mathrm{P}>0.05))$. 
TABLE 2

Pearson coefficients $(r)$ and $P$-values of correlations between stomatal density (stomata $\mathrm{mm}^{-2}$ ), leaf width, leaf length, leaf slenderness and leaf area, tree height and diameter of Rhizophora mangle trees, sampled in three different environments of the Xel-Há Park, Quintana Roo, Mexico

\begin{tabular}{|c|c|c|c|}
\hline Variable (1) & Variable (2) & Pearson & P-value \\
\hline \multirow[t]{6}{*}{ Stomatal density } & Leaf width & -0.31 & $<0.0001$ \\
\hline & Leaf length & -0.25 & 0.0009 \\
\hline & Area & -0.29 & 0.0001 \\
\hline & Slenderness & 0.27 & 0.0003 \\
\hline & Diameter & -0.33 & $<0.0001$ \\
\hline & Height & -0.32 & $<0.0001$ \\
\hline \multirow{5}{*}{ Leaf width } & Leaf length & 0.79 & $<0.0001$ \\
\hline & Area & 0.96 & $<0.0001$ \\
\hline & Slenderness & -0.74 & $<0.0001$ \\
\hline & Diameter & 0.33 & $<0.0001$ \\
\hline & Height & 0.37 & $<0.0001$ \\
\hline \multirow[t]{4}{*}{ Leaf length } & Area & 0.91 & $<0.0001$ \\
\hline & Slenderness & -0.21 & 0.0056 \\
\hline & Diameter & 0.03 & 0.7336 \\
\hline & Height & 0.02 & 0.8205 \\
\hline \multirow[t]{3}{*}{ Area } & Slenderness & -0.55 & $<0.0001$ \\
\hline & Diameter & 0.22 & 0.0031 \\
\hline & Height & 0.25 & 0.0008 \\
\hline \multirow[t]{2}{*}{ Slenderness } & Diameter & -0.46 & $<0.0001$ \\
\hline & Height & -0.54 & $<0.0001$ \\
\hline Diameter & Height & 0.71 & $<0.0001$ \\
\hline
\end{tabular}

in long-term hydroponic culture (Parida, Das, \& Mittra, 2004).

Leaves from the low salinity River site were the longest, however, there was no association between the length of the leaves and the size of the plants (height and stem circumference), which suggests that this variable has environmental plasticity independent of plant size. Leaf width on the other hand, showed a positive relationship with plant height and stem diameter. Mangrove leaves collected at the Xel-Há cove were comparable in length with typical mangrove leaves, which have lengths of 10-15 cm under optimum conditions (Canoy, 1975; Snedaker \& Brown, 1981). Only leaves from the River site were wider than $5 \mathrm{~cm}$, while leaves from the Lagoon and Beach sites were narrower than the reported standard of 5-7 cm (Canoy, 1975; Snedaker \& Brown, 1981). Leaf slenderness also reflected the salinity gradient and had the lowest values at the River site and the highest value at the Beach site. Leaf area was lowest at the Lagoon site, given that the shortest and narrowest leaves were collected here, indicating some kind of environmental stress affecting leaf expansion. Mangrove leaf size can be affected by salinity, as shown by Parida et al. (2004) long-term hydroponic culture of Bruguiera parviflora, in which leaf size reduction with $\mathrm{NaCL}$ treatment was attributed

TABLE 3

Correlation coefficients $(R)$ and their significance value $(P)$ between the biological data set (stomatal density, leaf width, leaf length, stem diameter, tree height, slenderness, and leaf area) and the first and second principal components that synthesize them. The eigenvalue $(\lambda)$ and percent of the data variability accounted by principal each component are shown in the second upper row

\begin{tabular}{lcccc}
\multicolumn{1}{c}{ Variable } & Principal component 1 & $(\lambda=3.22 ; 53.7 \%)$ & Principal component $2(\lambda=1.64 ; 27.4 \%)$ \\
Stomatal density & $\mathrm{r}$ & $\mathrm{P}$ & $\mathrm{r}$ & $\mathrm{P}$ \\
Leaf width $(\mathrm{cm})$ & -0.57 & $<.0001$ & 0.36 & 0.005 \\
Leaf length $(\mathrm{cm})$ & -0.52 & $<.0001$ & 0.19 & 0.14 \\
Trunk diameter $(\mathrm{cm})$ & 0.95 & $<.0001$ & 0.57 & $<.0001$ \\
Height $(\mathrm{m})$ & 0.78 & $<.0001$ & -0.72 & $<.0001$ \\
Slenderness & 0.52 & $<.0001$ & -0.71 & $<.0001$ \\
Leaf area $\left(\mathrm{cm}^{2}\right)$ & 0.54 & $<.0001$ & 0.29 & 0.03 \\
\hline
\end{tabular}




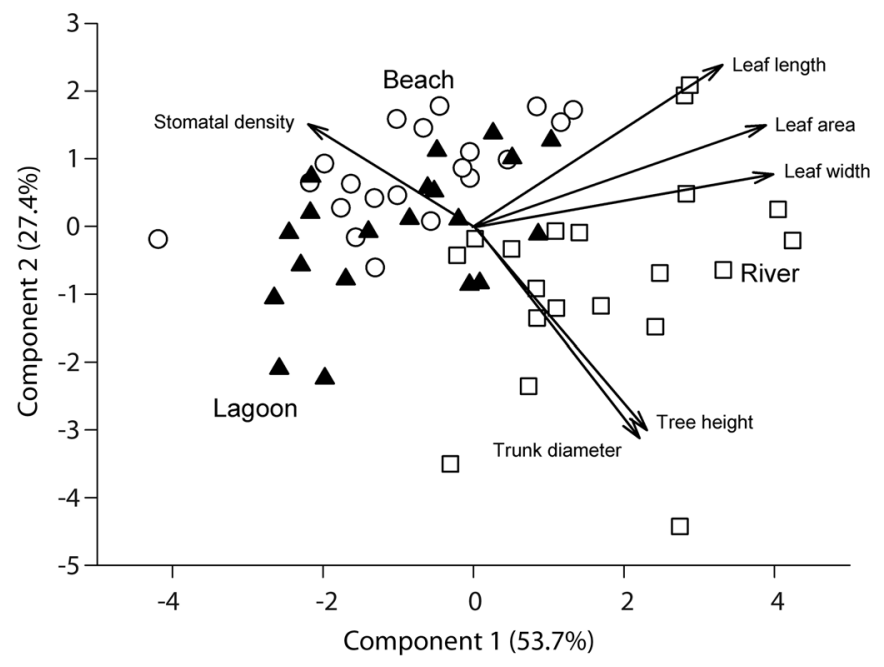

Fig. 4. Biplot indicating the distribution of the scores from the Principal Component Analysis and the variables used for Rhizophora mangle tree and leaf characterization in three sampling sites (River, squares; Lagoon, triangles; Beach, circles) within the Xel-Há cove, Quintana Roo, Mexico. Each data point represents a tree.

to reduction of intercellular space. $R$. stylosa saplings grown at salinities greater than $25 \%$ seawater, have sharp and significant decreases in leaf, stem and root dry weights (Clough, 1984). In Avicennia germinans high salinities increase leaf mortality and reduce leaf expansion significantly (Suárez \& Medina, 2005). A comparative study in A. germinans, L. racemo$s a$ and $R$. mangle showed that elevated environmental salinities lead to increased osmolality of the leaf sap and leaf area reduction, which was especially pronounced in $R$. mangle (Medina \& Francisco, 1997).

Initially we hypothesized that leaves from environments with higher salinities would have lower stomatal density in order to reduce water loss. This is based on observations made on the mangrove Kandelia candel (Rhizophoraceae) (Hwang \& Chen, 1995) in which leaf size and stomatal density were reduced at high salinity (> $400 \mathrm{mM} \mathrm{NaCl}$, aprox. $23 \mathrm{PSU}$ ) in comparison with intermediate and low salinity (Hwang \& Chen, 1995). Surprisingly, we observed the highest stomatal densities at the highest salinity sites, Lagoon and Beach. Leaf size responded to salinity as expected: smaller leaves in higher salinities. Water deficit can affect leaf size by decreasing cell size and causing an increase in stomatal density (Quarrie \& Jones, 1977; Spence, Wu, Sharpe, \& Clark, 1986; Martínez, Silva, Ledent, \& Pinto, 2007; Xu \& Zhou, 2008). A study on L. racemosa and A. germinans did not show reductions of stomatal density with increases in salinity (Lovelock \& Feller, 2003), which was confirmed by Schwarzbachl and Ricklefs (2001). Dahdouh-Guebas et al. (2004) also failed to find significant differences in stomatal density with elevated salinities in A. germinans. Stomatal density may increase with leaf size reduction to overcome a simple geometric practicality of fitting enough functional stomatal units per unit of leaf surface area to meet the desired $\mathrm{CO}_{2}$ flux and to service photosynthetic capacity (Franks \& Farquhar, 2007). Hetherington and Woodward (2003) for example demonstrated that there was a strong relationship between stomatal size and density. In addition, stomatal length seems to decrease with increasing droughts (Aasamaa, Sober, \& Rahi, 2001). Smaller stomata have faster dynamic characteristics, which has implications for improved long-term water use efficiency and lower risk of disruption of the leaf hydraulic system (Drake, Froend, \& Franks, 
2013), allowing the stomata to open and close faster and thus respond rapidly to environmental change (Hetherington \& Woodward, 2003). Salisbury (1928) found that stomatal density was inversely related to leaf size, due to a higher cell insertion (number of cells per unit area) in smaller leaves. However, at a cellular level the stomatal index remains constant. Stomata are produced early in leaf expansion so their density is at its maximum when young, and then decreases as the leaf expands to a relatively stable density, independently of the level of cell insertion or area (Gay \& Hurd, 1975). Our results confirm that stomatal density is inversely related to leaf area, especially leaf width, and that salinity may increase stomatal density by causing reduction of leaf size.

\section{ACKNOWLEDGMENTS}

We sincerely like to thank the effort of the anonymous reviewers. This work is part of the doctoral studies of Joanne R. Peel, postgraduate student at Universidad Autonoma Metropolitana (UAM), and her tutor Jordan Golubov, in the degree of "Doctorado en Ciencias Biologicas y de la Salud". Funding was provided by CONACyT student scholarship (243375/ 374628). We thank Instituto de Ecología, UNAM for financial support and infrastructure to carry out this project, as well as the Xel-Há Park for site access permits and support during field work. JG and MCM acknowledge a sabbatical scholarship provided by CONACyT and DGAPA UNAM respectively. We thank Gregory Penn (New Mexico State University) who thoroughly reviewed the manuscript and significantly improved it.

\section{RESUMEN}

\footnotetext{
Variación en la densidad estomática, área foliar y tamaño de Rhizophora mangle (Malpighiales: Rhizophoraceae) a lo largo de un gradiente de salinidad en el Caribe Mexicano. Los manglares tienen varios mecanismos de resistencia salina y la mayoría de las especies presentan algunas características xeromórficas con el fin de conservar el agua. El tamaño de la hoja y la densidad de los estomas desempeñan un papel importante en el
}

mantenimiento del equilibrio hídrico. El intercambio de gases puede mediarse mediante la regulación de la apertura de los estomas, así como el número de estomas sobre la epidermis, dos características que pueden variar intraespecíficamente en función las condiciones ambientales, tales como el estrés hídrico. Rhizophora mangle es una de las especies de mayor importancia en América del Norte y Sur, y de África occidental. El objetivo de este trabajo fue evaluar los efectos de la salinidad sobre la densidad de los estomas, el tamaño de la hoja y el tamaño de las plantas de Rhizophora mangle y determinar si existe una relación entre las tres variables, comparándose tres ambientes diferentes a lo largo de un gradiente natural de salinidad en Xel-Há, Quintana Roo, México. La hipótesis fue que los ambientes de alta salinidad producirían plantas más pequeñas, con hojas más pequeñas y menos estomas. Se seleccionaron tres sitios de estudio con condiciones ambientales diferentes y se midió la salinidad cada mes. Un total de 542 plantas fueron etiquetadas en los tres sitios, y se midió su altura y diámetro del tronco. Se recolectaron tres hojas de 20 árboles en cada uno de los sitios, y se obtuvo el área de cada hoja. La densidad estomática se midió mediante la técnica de microrelieve con barniz de uñas, observando diez $1 \mathrm{~mm}$ cuadrados bajo un microscopio óptico. Se utilizó un análisis de componentes principales para determinar la asociación entre altura de árbol, área de hoja y densidad estomática. El gradiente de salinidad se vio reflejado en el tamaño de las plantas, produciendo plantas más pequeñas en el sitio de alta salinidad. El largo de las hojas no se correlacionó con el tamaño de las plantas, por lo cual se concluyó que esta variable tiene plasticidad ambiental particular. Las hojas más grandes fueron encontradas en el sitio de baja salinidad y tuvieron densidades estomáticas menores. No se pudo observar que la densidad de estomas disminuyera con las altas salinidades. Estos resultados confirman que la densidad estomática es inversamente relacionada con el tamaño de la hoja, especialmente el ancho, y que la densidad estomática incrementa con la salinidad debido a la reducción del tamaño de hoja.

Palabras clave: altura, área foliar, densidad estomática, estrés hídrico, manglar, plasticidad de hoja.

\section{REFERENCES}

Aasamaa, K., Sober, A., \& Rahi, M. (2001). Leaf anatomical characteristics associated with shoot hydraulic conductance, stomatal conductance and stomatal sensitivity to changes of leaf water status in temperate deciduous trees. Australian Journal of Plant Physiology, 28(8), 765-774.

Araujo, R. J., Jaramillo, J. C., \& Snedaker, S. C. (1997). LAI and leaf size differences in two red mangrove forest types in South Florida. Bulletin of Marine Sciences, 60(3), 643-647. 
Aziz, I., \& Khan, M. A. (2001). Effect of seawater on the growth, ion content and water potential of Rhizophora mucronata Lam. Journal of Plant Research, 114(3), 369-373.

Ball, M. C. (1988). Ecophysiology of mangroves. Trees, 2(3), 129-142.

Ball, M. C., \& Pidsley, S. M. (1995). Growth responses to salinity in relation to distribution of two mangrove species, Sonneratia alba and $S$. lanceolata, in northern Australia. Functional Ecology, 9(1), 77-85.

Barbien, G., Vallone, S., Orsini, F., Paradiso, R., De Pascale, S., Negre-Zakharov, F., \& Maggio, A. (2012). Stomatal density and metabolic determinants mediate salt stress adaptation and water use efficiency in basil (Ocimum basilicum L.). Journal of Plant Physiology, 169(17), 1737-1746.

Beerling, D. J., \& Kelly, C. K. (1997). Stomatal density responses of temperate wodland plants over the past seven decades of $\mathrm{CO}_{2}$ increase: A comparison of Salisbury (1927) with contemporary data. American Journal of Botany, 84(11), 1572-1583.

Brewer, C. A. (1992). Responses by stomata on leaves to microenvironmental conditions. In C. A. Goldman (Ed.), Tested Studies for Laboratory Teaching (pp. 67-75). Proceedings of the 13th Workshop/Conference of the Association for Biology Laboratory Education (ABLE).

Bristow, J. M., \& Looi, A. (1968). Effects of carbon dioxide on the growth and morphogenisis of Marsilea. American Journal of Botany, 55(8), 884-889.

Canoy, M. J. (1975). Diversity and stability in a Puerto Rican Rhizophora mangle L. forest. In G. Walsh, S. C. Snedaker, \& H. Teas (Eds.), Proceedings of International Symposium on Biology and Management of Mangroves (Vol. I., pp. 344-356). Gainesville, Florida: Institute for Food and Agricultural Science, University of Florida.

Ciha, A. J., \& Brun, W. A. (1975). Stomatal size and frequency in soybeans. Crop Science, 15(3), 309-313.

Clough, B. F. (1984). Growth and salt balance of the mangroves Avicennia marina (Forsk.) Vierh. and Rhizophora stylosa in relation to salinity. Australian Journal Plant Physiology, 11(5), 419-430.

CONABIO (2009). Manglares de México: Extensión y distribución. Mexico City: Comisión Nacional para el conocimiento y uso de la biodiversidad.

Connor, D. J. (1969). Growth of grey mangrove (Avicennia marina) in nutrient culture. Biotropica, 1(2), 36-40.

Dahdouh-Guebas, F., De Bondt, R., Abesinghe, P. D., Kairo, J. G., Cannicci, S., Triest, L., \& Koedam, N. (2004). Comparative study of the disjunct zonation pattern of the grey mangrove Avicennia marina
(Forsk.) Vierh. in Gazi Bay (Kenya). Bulletin of Marine Science, 74(2), 237-252.

Das, S., \& Ghose, M. (1993). Morphology of stomata and leaf hairs of some halophytes from Sundarbans, West Bengal. Phytomorphology, 43, 59-70.

Downton, W. J. S. (1982). Growth and osmotic relations of the mangrove Avicennia marina, as influenced by salinity. Functional Plant Biology, 9(5), 519-528.

Drake, P. L., Froend, R. H., \& Franks, P. J. (2013). Smaller, faster stomata: Scaling of stomatal size, rate of response, and stomatal conductance. Journal of Experimental Botany, 64(2), 495-505.

Duke, J. A. (1983). Rhizophora mangle L. Handbook of Energy Crops. Retrieved from https://www.hort. purdue.edu/newcrop/duke_energy/Rhizophora mangle.html

Ellison, A., Farnsworth, E., \& Moore, G. (2015). Rhizophora mangle. The IUCN Red List of Threatened Species. Retrieved from http://www.iucnredlist.org/ details/178851/0

Franks, P. J., \& Farquhar, G. D. (2007). The mechanical diversity of stomata and its significance in gasexchange control. Plant Physiology, 143(1), 78-87.

Gay, A. P., \& Hurd, R. G. (1975). The influence of light on stomatal density in the Tomato. New Phytology, 75(1), 37-46

Hetherington, A. M., \& Woodward, F. I. (2003). The role of stomata in sensing and driving environmental change. Nature, 424(6951), 901-908.

Hill, K. (2001). Rhizophora mangle, Smithsonian Marine Station Fort Pierce. Retrieved from http://www. sms.si.edu/irLspec/Rhizop_mangle.htm\#reducing conditions

Huner, N. P. A., Palta, J. P., Li, P. H., \& Carter, J. V. (1981). Anatomical changes in leaves of Puma Rye in response to growth at cold-hardening temperatures. Botanical Gazette, 142, 55-62.

Hwang, Y. H., \& Chen, S. C. (1995). Anatomical responses in Kandelia candel (L.) Druce seedlings growing in the presence of different concentrations of $\mathrm{NaCl}$. Botanical Bulletin of Academia Sinica, 36, 181-188.

Krauss, K. W., \& Allen, J. A. (2003). Influences of salinity and shade on seedling photosynthesis and growth of two mangrove species, Rhizophora mangle and Bruguiera sexangula, introduced to Hawaii. Aquatic Botany, 77(4), 311-324.

López Portillo, J., \& Ezcurra, E. (2002). Los manglares de México: una revisión. Madera y Bosques, número especial, 27-51. 
Lovelock, C. E., \& Feller, I. C. (2003). Photosynthetic performance and resource utilization of two mangrove species coexisting in a hypersaline scrub forest. Oecologia, 134(4), 455-62.

Lugo, A. E., Cintrón, G., \& Goenaga, C. (1981). Mangrove ecosystems under stress. In W. Barrett \& R. Rosenberg (Eds.), Stress Effects on Natural Ecosystems (pp. 129-153). Great Britain: John Wiley \& Sons Ltd.

Lugo, A. E., \& Snedaker, S. C. (1974). The ecology of mangroves. Annual Review of Ecology and Systematics, 5, 39-64.

Martínez, J. P., Silva, H., Ledent, J. F., \& Pinto, M. (2007). Effect of drought stress on the osmotic adjustment, cell wall elasticity and cell volume of six cultivars of common beans (Phaseolus vulgaris L.). European Journal of Agronomy, 26(1), 30-38.

Medina, E., \& Francisco, M. (1997). Osmolality and $\delta^{13} \mathrm{C}$ of leaf tissues of mangrove species from environments of contrasting rainfall and salinity. Estuarine, Coastal and Shelf Science, 45(3), 337-344.

Mehlig, U. (2006). Phenology of the red mangrove, Rhizophora mangle L., in the Caeté Estuary, Pará, equatorial Brazil. Aquatic Botany, 84(2), 158-164.

Orellana-Lanza, R., Espadas, C., Conde, C., \& Gay, C. (2009). Atlas. Escenarios de cambio climático en la Península de Yucatán. Mérida, Yucatán, Mexico: Centro de Investigación Científica de Yucatán, A.C.

Organismo de cuenca Península de Yucatán. (2008). Cuerpo de agua denominado caleta Xel-Há, localizado en el estado de Quintana Roo (Informe técnico). México: Organismo de cuenca Península de Yucatán.

Pääkkönen, E., Vahala, J., Pohjolal, M., Holopainen, T., \& Kärenlampi, L. (1998). Physiological, stomatal and ultrastructural ozone responses in birch (Betula pendula Roth.) are modified by water stress. Plant, Cell \& Environment, 21(7), 671-684.

Parida, A. K., Das, A. B., \& Mittra, B. (2004). Effects of salt on growth, ion accumulation, photosynthesis and leaf anatomy of the mangrove, Bruguiera parviflora. Trees - Structure and Function, 18(2), 167-174.

Pearce, D. W., Millard, S., Bray, D. F., \& Rood, S. B. (2005). Stomatal characteristics of riparian poplar species in a semi-arid environment. Tree Physiology, 26(2), 211-218.

Quarrie, S. A., \& Jones, H. G. (1977). Effects of abscisic acid and water stress on development and morphology of wheat. Journal of Experimental Botany, 28(1), 192-203.

Romero-Aranda, R., Soria, T., \& Cuartero, J. (2001). Tomato plant-water uptake and plant-water relationships under saline growth conditions. Plant Science, 160(6), 265-272.

Saenger, P. (2002). Mangrove Ecology, Silviculture and Conservation. Dordrecht, The Netherlands: Kluwer Academic Publishers.

Salisbury, E. J. (1928). On the causes and ecological significance of stomatal frequency, with special reference to the woodland flora. Philosophical Transaction of the Royal Society of London, Series B, 216, 1-65.

Sam, O., Jeréz, E., Dell’Amico, J., \& Ruiz-Sanchez, M. C. (2000). Water stress induced changes in anatomy of tomato leaf epidermes. Biologia Plantarum, 43(2), 275-277.

Schwarzbachl, A. E., \& Ricklefs, R. E. (2001). The use of molecular data in mangrove plant research. Wetlands, Ecology and Management, 9(3), 195-201.

Siefert, A., Violle, C., Chalmandrier, L., Albert, C. H., Taudiere, A., Fajardo, A., Aarssen, L. W., ..., \& Wardle, D. A. (2015). A global meta-analysis of the relative extent of intraspecific trait variation in plant communities. Ecology Letters, 18(12), 1406-1419.

Snedaker, S. C., \& Brown, M. S. (1981). Water quality and mangrove ecosystem dynamics. EPA-600/4-8 1-002. Florida, USA: United States Environmental Protection Agency, Gulf Breeze.

Spence, R. D., Wu, H., Sharpe, P. J. H., \& Clark, K. G. (1986). Water stress effects on guard cell anatomy and the mechanical advantage of the epidermal cells. Plant, Cell \& Environment, 9(3), 197-202.

Suárez, N., \& Medina, E. (2005). Salinity effect on plant growth and leaf demography of the mangrove, Avicennia germinans L. Trees, 19(6), 722-728.

Tomlinson, P. B. (1986). The botany of mangroves. Cambrige: Cambridge University Press.

Westoby, M., Falster, D. S., Moles, A. T., Vesk, P. A., \& Wright, I. J. (2002). Plant ecological strategies: Some leading dimensions of variation between species. Annual Review of Ecology and Systematics, 33, 125-159.

Woodward, F. I., \& Bazzaz, F. A. (1988). The Responses of stomatal density to $\mathrm{CO}_{2}$ partial pressure. Journal of Experimental Botany, 39(12), 1771-1781.

Xu, Z., \& Zhou, G. (2008). Responses of leaf stomatal density to water status and its relationship with photosynthesis in a grass. Journal of Experimental Botany, 59(12), 3317-25.

Zhang, Y., Zheng, Q., \& Tyree, M. T. (2012). Factors controlling plasticity of leaf morphology in Robinia pseudoacacia L. I: height-associated variation in leaf structure. Annals of Forest Science, 69, 29-37. 